These observations underscore that ketoacidosis can be prevented by simple and very cheap means available even in countries that face major economic problems. In this context it is of note, that our colleagues in Moscow have recently shown, that it is possible to safely improve metabolic control even if blood glucose test strips are not available and patients use only urine glucose self monitoring [3].

Adherance to a strict diet does not lead to a good quality of glycaemic control, if diabetes therapy is not based upon sufficient insulin treatment and appropriate patient education. A most impressive example for such a diet failure is the Bucharest standard treatment as evaluated in the Bucharest-Düsseldorf Study [2]. Although these patients had a very strict diabetes diet, and education was focused upon adherence to diet, an approach we have recently called "obedience training" [4], they had very high $\mathrm{HbA}_{1}$ levels (about $12.6 \%$ ), a high incidence of ketoacidosis ( 0.16 cases per patient per year), high hospitalisation rates and an excessive mortality rate. Comparably high $\mathrm{HbA}_{1}$ values have also been found in the United States, where the most rigid dietary regimens are imposed on diabetic patients using exchange lists even for vegetables, dairy products, meat, etc. [5].

Very often, money available for the care of diabetic patients can be allocated by redistribution [3]. Thus, even in countries under most stringent economic conditions, drugs which are ineffective, unnecessary or which could be easily substitued by cheaper preparations, are used in diabetic patients, such as calciumdobesilate, pentoxifylline, angiotensin converting enzymeinhibitors, lipid lowering drugs and others. It has been calculated that at a cost of DM 190 (US $\$ 118$ ) per patient per year, effective and safe insulin therapy is possible [6].

Finally, we want to draw attention to the efforts of other Romanian colleagues, both in Bucharest and other cities in the country, who have put into practise the knowledge gained from the 1982 DESG workshop in Bucharest and the Bucharest-Düsseldorf Study [2] by initiating structured treatment and teaching

\section{Increased plasma endothelin in diabetes: an atherosclerosis marker?}

Dear Sir,

Following an article in Diabetologia [1], a letter [2] - and the response from the authors [3] - regarding the role of endothelin as a marker of endothelial dysfunction in diabetes mellitus have been published. We would like to present our own experience on this subject.

We have measured plasma endothelin levels in 79 diabetic patients [23 Type 1 (age 20-50 years) and 56 Type 2 (age 5578 years)], and in 100 young ( $20-50$ years) and 36 older (5578 years) healthy control subjects.

In normotensive uncomplicated Type 1 diabetic patients $(n=13)$, the plasma endothelin levels were not significantly different from those of the age-matched control subjects. Microalbuminuria ( $>30 \mu \mathrm{g} / \mathrm{ml} ; n=10$ ) and concomitant retinopathy together with well-preserved kidney function were associated with significantly elevated endothelin levels in Type 1 diabetic patients as compared with their age-matched control subjects $(1.6 \pm 0.3$ vs $0.54 \pm 0.39 \mathrm{pg} / \mathrm{ml}, p<0.05)$.

Corresponding author: Dr. R. Patiño, Center for the Study of Hypertension, Diabetes and Obesity, Hospital Universitario San Carlos, Complutense University, E-28040 Madrid, Spain programmes for Type 1 diabetic patients. In fact, following the Declaration of San Vincente such effective treatment should be offered to all diabetic patients of Romania. The precious manpower of the nurses currently working in the intensive care unit established for the treatment of diabetic ketoacidosis could be redistributed to diabetes education, thus improving the lives of the patients and the work satisfaction of those involved in diabetes care.

Sincerely yours,

I. Mühlhauser, V. Jörgens, M. Berger

\section{References}

1. Wagener W, Overmann H, Bott U, Mühlhauser I, Berger M (1993) Do type 1 diabetic patients practise 'liberalized diet'? Diabetologia 36: A 33 (Abstract)

2. Mühlhauser I, Bruckner I, Berger M et al. (1987) Evaluation of an intensified insulin treatment and teaching programme as routine management of type 1 (insulin-dependent) diabetes. The Bucharest-Düsseldorf Study. Diabetologia 30: 681-690

3. Starostina EG, Antsiferov M, Galstyan GR et al. (1994) Effectiveness and cost-benefit analysis of intensive treatment and teaching programmes for type 1 (insulin-dependent) diabetes mellitus in Moscow - blood glucose versus urine glucose selfmonitoring. Diabetologia 37: 170-176

4. Mühlhauser I, Berger M (1993) Diabetes education and insulin therapy: when will they ever learn? J Int Med 233: 321-326

5. Klein R, Klein BEK, Moss SE, Davis MD, DeMets DL (1988) Glycosylated hemoglobin predicts the incidence and progression of diabetic retinopathy. JAMA 260: 2864-2871

6. Chantelau E (1993) Diabetes treatment in developing countries. Lancet 342: 620 (Letter)

Our results show that endothelin levels increase with age in normal subjects $(0.54 \pm 0.39 \mathrm{pg} / \mathrm{ml}$ in the young vs $1.54 \pm$ $0.9 \mathrm{pg} / \mathrm{ml}$ in the elderly, $p<0.01$ ), and as could be expected, normotensive, normoalbuminuric Type 2 diabetic patients $(n=28)$ show endothelin levels which are not statistically different from those of the control subjects. Type 2 diabetic patients with microalbuminuria $(n=10)$, in contrast to their Type 1 counterparts, also have plasma endothelin levels which are comparable to those of control subjects.

However, when macrovascular disease $(n=16)$ was considered (peripheral and coronary artery diseases) in Type 2 diabetic patients, the plasma endothelin levels were found to be significantly elevated as compared with those of 40 Type 2 diabetic patients without vascular complications $(1.56 \pm 0.6$ vs $2.3 \pm 0.9 \mathrm{pg} / \mathrm{ml}, p<0.01$ ) [4].

When retinopathy was investigated, the results continued to indicate that it is macrovascular disease which is inducing endothelin. Patients with retinopathy but without macrovascular disease ( $n=10$ of 40 , endothelin $1.43 \pm 0.4$ ) had endothelin levels which were not significantly different from those of the control group $(1.54 \pm 0.9 \mathrm{pg} / \mathrm{ml})$. Patients with retinopathy and macrovascular disease $(n=9$ of 16$)$ showed significantly elevated levels $(2.5 \pm 0.9 \mathrm{pg} / \mathrm{ml}, p<0.01)[5]$.

Diabetes is an atherogenic polygenic disease. In Type 1 diabetes there is a strong association between microalbuminuria and vascular disease [6]. This association is much less manifest in Type 2 diabetes, which itself is associated with the insulin-resistance syndrome [7] and also with the presence of other risk factors. 
Our data clearly indicate that endothelin is increased in Type 1 diabetic patients with microalbuminuria and in Type 2 diabetic patients with overt atherosclerosis.

Further research is indicated to classify the role of endothelin as a marker of vascular dysfunction.

Yours sincerely,

R. Patiño, J. Ibarra, A.Molino, R. Fernandez-Durango, J. Moya, A. Fernandez-Cruz

\section{References}

1. Stehouwer CDA, Zellenrath P, Polak BCP et al. (1992) von Willebrand factor and early diabetic retinopathy: no evidence for a relationship in patients with type 1 (insulin-dependent) diabetes mellitus and normal urinary albumin excretion. Diabetologia 35: 555-559

2. Vermes I, Spooren PFMJ, Kalsbeek-Batenburg EM, Haanen $\mathrm{C}$ (1993) In addition to von Willebrand factor and urinary al-

\section{Response from the authors}

\section{Dear Sir,}

We thank Dr Patino and co-workers for their interesting data. They observed normal plasma endothelin concentrations in normotensive uncomplicated Type 1 diabetes. In contrast, we found that endothelin levels were lower in men with uncomplicated Type 1 diabetes than in male control subjects [1]. Plasma endothelin concentrations may be influenced by gender [2]. This finding [2] may explain the difference between our results [1] and those of Patino et al. It would, therefore, be interesting to reanalyse their data after stratification by sex.

The fact that Patino et al. found plasma endothelin concentrations to be elevated in patients with Type 1 diabetes complicated by microalbuminuria is consistent with a large body of evidence showing that such patients have generalised vascular and endothelial dysfunction $[3,4]$.

It is somewhat surprising that Patino et al. observed normal endothelin levels in microalbuminuric (and normoalbuminuric) Type 2 diabetic patients. First, their data appear to be at variance with the largest study on this subject to date [5]. Second, the group of microalbuminuric patients was relatively small, leaving open the possibility of a statistical type II error. Third, microalbuminuria is, in fact, very strongly associated with atherosclerotic vascular disease in Type 2 diabetes $[6,7]$. Fourth, insulin stimulates endothelin production in vitro [8], suggesting that it may be worthwhile to investigate the relationship between endothelin concentrations and insulin resistance and the hyperinsulinaemia that accompanies it.

In view of endothelin's widespread actions, we do agree that further study of its role in diabetic micro- and macroangiopathy is necessary. At present, however, the plasma concentration of von Willebrand factor, an endothelium-derived glycoprotein, seems to be the best available marker of endothelial injury in Type 2 diabetes [7].

Yours sincerely,

C.D.A. Stehouwer

Corresponding author: Dr. C.D.A. Stehouwer, Department of Internal Medicine, Institute for Cardiovascular Research, Free University Hospital, De Boelelaan 1117, NL-1081 HV Amsterdam, The Netherlands bumin excretion, plasma endothelin is an indicator of endothelial dysfunction in diabetes mellitus. Diabetologia 36: 472473 (Letter)

3. Stehouwer CDA (1993) Response from the authors. Diabetologia 36: 473 (Letter)

4. Lerman A, Edwards BS, Hallet JW, Heublein DM, Sandberg SM, Burnett JC (1991) Circulating and tissue endothelin immunoreactivity in advanced atherosclerosis. $\mathrm{N}$ Engl $\mathrm{J}$ Med 325:997-1001

5. Kawamura M, Ohgawara H, Naruse M et al. (1992) Increased plasma endothelin in NIDDM patients with retinopathy. Diabetes Care 15: 1396-1397

6. Earle K, Walker J, Hill C, Viberti GC (1992) Familial clustering of cardiovascular disease in patients with insulin dependent diabetes and nephropathy. N Engl J Med 326: 673677

7. McClain DA, Henry RR, Ullrich A, Olefsky JM (1988) Restriction-fragment-length polymorphism in insulin-receptor gene and insulin resistance in NIDDM. Diabetes 37: 10711075

\section{References}

1. Smulders RA, Stehouwer CDA, Olthof GC, van Kamp GJ, Donker AJM (1992) Plasma endothelin levels and vascular effects of L-arginine in type 1 (insulin-dependent) diabetes. Diabetologia 35 [Suppl 1]: A 19 (Abstract)

2. Polderman KH, Stehouwer CDA, van Kamp GJ, Dekker GA, Verheugt FWA, Gooren LJG (1993) Influence of sex hormones on plasma levels of endothelin. Ann Intern Med 186: $429-432$

3. Deckert T, Feldt-Rasmussen B, Borch-Johnsen K, Jensen T, Kofoed-Enevoldsen A (1989) Albuminuria reflects widespread vascular damage. The Steno hypothesis. Diabetologia 32: 219-226

4. Stehouwer CDA, Donker AJM (1993) Urinary albumin excretion and cardiovascular disease risk in diabetes mellitus: is endothelial dysfunction the missing link? J Nephrol 6: 72-92

5. Takahashi K, Ghatei MA, Lam HC, O'Halloran DJ, Bloom SR (1990) Elevated plasma endothelin in patients with diabetes mellitus. Diabetologia 33: 306-310

6. Mattock MB, Morrish NJ, Viberti GC, Keen H, Fitzgerald AP, Jackson G (1992) Prospective study of microalbuminuria as predictor of mortality in non-insulin-dependent diabetes mellitus. Diabetes 41: 736-741

7. Stehouwer CDA, Nauta JJP, Zeldenrust GC, Hackeng WHL, Donker AJM, den Ottolander GJH (1992) Urinary albumin excretion, cardiovascular disease, and endothelial dysfunction in non-insulin-dependent diabetes mellitus. Lancet 340: 319323

8. Hu RM, Levin ER, Pedram A, Frank HJL (1993) Insulin stimulates production and secretion of endothelin from bovine endothelial cells. Diabetes 42: 351-358 